OPEN ACCESS

Edited by:

Hubert Vaudry,

Université de Rouen, France

Reviewed by:

Manuel Tena-Sempere,

University of Cordoba, Spain

Hana Zemkova,

Academy of Sciences of the Czech

Republic (ASCR), Czechia

*Correspondence:

Yoshihisa Uenoyama

uenoyama@nagoya-u.jp

Specialty section:

This article was submitted to

Neuroendocrine Science,

a section of the journal

Frontiers in Endocrinology

Received: 14 June 2021

Accepted: 23 August 2021 Published: 09 September 2021

Citation:

Uenoyama $Y$, Nagae $M$,

Tsuchida $H$, Inoue $N$ and

Tsukamura H (2021) Role of KNDy

Neurons Expressing Kisspeptin,

Neurokinin B, and Dynorphin A as a

GnRH Pulse Generator Controlling

Mammalian Reproduction.

Front. Endocrinol. 12:724632.

doi: 10.3389/fendo.2021.724632

\section{Role of KNDy Neurons Expressing Kisspeptin, Neurokinin B, and Dynorphin A as a GnRH Pulse Generator Controlling Mammalian Reproduction}

\author{
Yoshihisa Uenoyama*, Mayuko Nagae, Hitomi Tsuchida, Naoko Inoue and Hiroko Tsukamura \\ Laboratory of Animal Reproduction, Graduate School of Bioagricultural Sciences, Nagoya University, Nagoya, Japan
}

Increasing evidence accumulated during the past two decades has demonstrated that the then-novel kisspeptin, which was discovered in 2001, the known neuropeptides neurokinin B and dynorphin A, which were discovered in 1983 and 1979, respectively, and their G-protein-coupled receptors, serve as key molecules that control reproduction in mammals. The present review provides a brief historical background and a summary of our recent understanding of the roles of hypothalamic neurons expressing kisspeptin, neurokinin B, and dynorphin A, referred to as KNDy neurons, in the central mechanism underlying gonadotropin-releasing hormone $(\mathrm{GnRH})$ pulse generation and subsequent tonic gonadotropin release that controls mammalian reproduction.

Keywords: Kiss1, Tac3, Pdyn, GPR54, NK3 receptor, k-opioid receptor

\section{INTRODUCTION}

Peptides play critical roles in the nervous systems of both invertebrates and vertebrates alike. The release of peptides as intercellular signaling molecules is an evolutionarily ancient property of neurons $(1,2)$. In fact, the nervous systems in cnidarians, a class of mostly aquatic animals that have existed for over 630 million years, are mainly controlled by peptidergic signals (2). Several signaling peptides were discovered in cnidarians and most of them were characterized by C-terminal amidation (3). These socalled neuropeptides are stored in intracellular neurosecretory vesicles until being secreted by exocytosis. Once secreted, these neuropeptides act on target cells by binding to and activating plasma membrane receptors, leading to changes in the intracellular signaling system.

The G-protein-coupled receptors (GPCRs) represent the single largest family of plasma membrane receptors, encompassing about 860 members in humans (4). The concept that these GPCRs may form a supergene family was derived from the discovery in 1986 that the $\beta 2$-adrenergic receptors and the opsins share a seven-transmembrane domain topology (5). At that time, the $\beta 2$ adrenergic receptors and the opsins were not known to have much in common except for coupling to G-proteins to elicit the intracellular signaling system. The structural feature of the seventransmembrane domain topology allowed a search for putative GPCRs in the genome, resulting in the discovery of a large number of GPCRs. The GPCRs are split into two major groups: olfactory 
and non-olfactory receptors. The non-olfactory GPCRs are further classified based on whether the endogenous ligand is known or unknown. Approximately $30 \%$ of the $~ 400$ nonolfactory human GPCRs have not been definitively paired with endogenous ligands and are designated as orphan GPCRs (6).

The present review focuses on neuropeptides, kisspeptin, neurokinin B and dynorphin A, and their GPCRs, because evidence accumulated during the past two decades has demonstrated that those three neuropeptides serve as key molecules that control reproduction via controlling pulsatile gonadotropin-releasing hormone $(\mathrm{GnRH})$ release in mammals. More specifically, the hypothalamic arcuate nucleus (ARC) neurons co-expressing kisspeptin/neurokinin B/dynorphin A, referred to as "KNDy neurons", are evident in mammals including rodents $(7-11)$, ruminants (12-14), and primates (15, 16) and the KNDy neurons are now considered to be largely responsible for $\mathrm{GnRH}$ pulse generation. In this review, we provide a historical background on the concept of $\mathrm{GnRH}$ pulse generator to control gametogenesis and steroidogenesis in mammals and a summary of our recent understanding of the roles of KNDy neurons in the central mechanism underlying GnRH pulse generation and subsequent tonic release of gonadotropins.

\section{THE DISCOVERY OF GNRH/ GONADOTROPIN PULSES}

One hundred years ago, in the 1920s, Smith (17) and Evans and Long (18) investigated the effects of hypophysectomy or the administration of pituitary extract on gonadal activities, and accordingly suggested that gonadal activities are regulated by one or more factors from the anterior pituitary gland (19). In the 1930s, luteinizing hormone (LH) and follicle-stimulating hormone (FSH) were successfully extracted from the anterior pituitary gland (20). The presence of GnRH [first named LHRH/FSH-RH or LHRH (21)], which controls gonadotropin release via the pituitary portal circulation, was predicted by Harris and Jacobsohn because they showed that the structure and function of the transplanted pituitary gland were maintained only when the pituitary gland was relocated under the median eminence in rats (22). Consequently, GnRH, which stimulates both LH and FSH release, was isolated in the early 1970s by two independent laboratories headed by Schally and Guillemin, respectively $(23,24)$.

In the early 1970s, Knobil and colleagues first demonstrated tonic (pulsatile) and cyclic (surge) gonadotropin release in female rhesus monkeys, used as a model of humans $(25,26)$, and predicted that the pulsatile nature of tonic gonadotropin release is likely caused by pulsatile $\mathrm{GnRH}$ stimulation to the anterior pituitary gland. Their pioneer study demonstrated the indispensable role of GnRH pulses in the control of gonadotropin release from the anterior pituitary gland (27). Indeed, plasma LH and FSH levels were kept at physiological levels only when $\mathrm{GnRH}$ was administrated in a pulsatile manner at a physiological frequency (once per hour) in female rhesus monkeys with a hypothalamic lesion (which resulted in the lack of endogenous GnRH release). In contrast, continuous $\mathrm{GnRH}$ administration paradoxically inhibited gonadotropin release in these monkeys (27). These findings indicated that GnRH pulses are needed to sustain the normal response of the anterior pituitary gland to GnRH stimulation. This knowledge has been exploited towards human reproductive technology and therapies. Indeed, some patients take pulsatile GnRH administration by an attached pump as a medical treatment to enhance folliculogenesis and recover ovulation (28), whereas chronic GnRH treatment is therapeutically used to inhibit sex steroid release in patients suffering from endometriosis as well as prostate cancer (29).

The pulsatile GnRH release was first described in ewes by measurements of GnRH in the pituitary portal blood in 1982 (30) and then examined in more detail in 1992 (31). These studies demonstrated that $\mathrm{GnRH}$ pulses detected in the pituitary portal circulation synchronized with LH pulses detected in the peripheral circulation.

\section{LOCALIZATION OF THE GNRH PULSE GENERATOR}

Pulsatile GnRH release from GnRH neurons into the pituitary portal circulation has been hypothesized to be driven by the mechanism of the so-called "GnRH pulse generator" $(32,33)$. The first experimental evidence for the localization of the $\mathrm{GnRH}$ pulse generator was provided by Halasz and Pupp (34): They designed a small knife cut to isolate the mediobasal hypothalamus $(\mathrm{MBH})$, leaving the region in contact with the pituitary gland but devoid of neural connections with the other brain regions. This complete deafferentation of the $\mathrm{MBH}$ failed to affect the testicular function (spermatogenesis) in males nor ovarian function (folliculogenesis) except for ovulation in female rats. These findings indicated that the complete deafferentation of the $\mathrm{MBH}$ disrupts the preovulatory $\mathrm{GnRH} / \mathrm{LH}$ surge but not the $\mathrm{GnRH}$ pulses that drive tonic gonadotropin release in female rats. Subsequent studies had confirmed that pulsatile $\mathrm{LH}$ release is not impaired by the complete hypothalamic deafferentation in rats $(35,36)$. Taken together, these findings indicated that the GnRH pulse generator would be located in the $\mathrm{MBH}$. Importantly, GnRH neuronal cell bodies are mainly located in the preoptic area (POA) and $\mathrm{GnRH}$ nerve terminals are located in the median eminence within the $\mathrm{MBH}$ in rats, indicating that the GnRH neurons themselves may not be involved in $\mathrm{GnRH}$ pulse generation and $\mathrm{GnRH}$ terminals would be an effector of GnRH pulse generator $(36,37)$.

Knobil and colleagues then established an important method to monitor GnRH pulse generator activity in the $\mathrm{MBH}$ via an electrophysiological approach in rhesus monkeys (38): This approach revealed that rhythmic increases in the multiple unit activity (termed MUA volleys) were accompanied by LH pulses detected in the peripheral circulation, when the recording electrodes were placed within the MBH. The MUA is the summation of the electrical activity of multiple neurons around the electrodes, and the origin of MUA volleys remained unknown at that time. This method was subsequently adapted to rats and 
goats (39-41) and successfully showed the MUA volleys in the $\mathrm{MBH}$ accompanied by $\mathrm{LH}$ pulses in such species as well. From then, significant effort was made to identify the intrinsic sources of the GnRH pulse generator for many years.

\section{THE ARC KISSPEPTIN NEURONS ARE A MAJOR REGULATOR OF GNRH/GONADOTROPIN PULSES}

At the turn of the twenty-first century, the discovery of kisspeptin provided a breakthrough in our understanding of the source of the GnRH pulse generator. Kisspeptin was first found as an endogenous ligand of GPR54, a then-orphan GPCR that shares significant homology with galanin receptors (42), from human placenta extract $(43,44)$. Kisspeptin was identified as a 54-amino-acid peptide cleaved from a 145-amino-acid prepropeptide in humans $(43,44)$. The C-terminal amidated 10 -amino-acid sequence of the peptide (Kp-10), which is essential and sufficient for interaction with GPR54, a Gqcoupled stimulatory GPCR (43), is identical among mammals, except for the $\mathrm{C}$-terminal phenylalanine which is changed to tyrosine in non-primate mammals (43-50). The precursor and mature kisspeptin with the C-terminal amidation in humans, rodents, and domestic animals are summarized in Figure 1A. Moreover, an indispensable role of kisspeptin as a neuropeptide in the central nervous system regulating reproduction in humans, was uncovered by two studies published in 2003 (51, 52): Two groups from the US and France independently demonstrated inactivating mutations of the GPR54 gene in patients suffering from hypogonadotropic hypogonadism with pubertal failure. To date, several Kiss1 or Gpr54 knockout rodents replicated hypogonadotropic hypogonadism as seen in humans (52-58). Later, a Turkish group demonstrated that patients carrying inactivating mutations of the KISS1 gene also exhibited hypogonadotropic hypogonadism (59). Taken together, these findings suggest that kisspeptin-GPR54 signaling serves as a key regulator for puberty onset and gonadotropin release in mammals.

Kisspeptin profoundly stimulated $\mathrm{GnRH}$ /gonadotropin release in mammals $(53,54,60-63)$. The previous studies demonstrated that central administration of full-length kisspeptin or $\mathrm{Kp}-10$ stimulated gonadotropin release in rodents (54, 60-62), ruminants (53), and primates (63). In addition, the stimulatory effect of kisspeptin on gonadotropin release was blocked by $\mathrm{GnRH}$ antagonists in both rodents $(60,61,64)$ and primates (63), indicating that kisspeptin-induced gonadotropin release is mediated by GnRH. The previous in vitro study showed that kisspeptin stimulates GnRH release from the rat hypothalamic tissue via stimulatory Gq-protein-mediated activation of phospholipase $\mathrm{C}$ and mobilization of intracellular $\mathrm{Ca}^{2+}$ (65). Further, several histological analyses showed that Gpr54 is expressed in a majority of $\mathrm{GnRH}$ neurons in mice $(53,66,67)$ and rats $(60,68)$. Electrophysiological studies revealed that kisspeptin exerted a potent direct depolarizing effect on $\mathrm{GnRH}$ neurons $(67,69,70)$. Further, GnRH neuron-specific Gpr54 knockout mice resulted in infertility, whereas the rescuing Gpr54 in GnRH neurons in global Gpr54 knockout mice restored fertility (71), suggesting that GPR54 solely in GnRH neurons is enough for fertility in mice. Taken together, these findings suggest that kisspeptin directly stimulates GnRH release via GPR54 expressed in $\mathrm{GnRH}$ neurons to lead consequent gonadotropin secretion in mammals.

There are two major populations of hypothalamic kisspeptin neurons: one population is localized in the ARC-inside the $\mathrm{MBH}$ - in most mammals examined to date, and the other population is localized more rostral regions such as the anteroventral periventricular nucleus (AVPV) in rodents (72-77) and the POA in most of the other mammals including ruminants $(12,14,46,78-83)$, primates $(50,63,84,85)$, and others $(47,48)$. The role of AVPV/POA kisspeptin neurons in generating $\mathrm{GnRH} / \mathrm{LH}$ surge in females was reviewed elsewhere (86-88). Circumstantial evidence suggesting that ARC kisspeptin neurons are an intrinsic source of the GnRH pulse generator has been accumulated as follows. When the MUA is measured in goats through recoding electrodes targeted to the vicinity of the ARC kisspeptin neurons, MUA volleys are found at regular intervals and are synchronized with LH pulses $(13,46)$. Further, recent in vivo GCaMP6 fiber photometry technology revealed that ARC kisspeptin neurons exhibited rhythmic increases in intracellular $\mathrm{Ca}^{2+}$ accompanied by $\mathrm{LH}$ pulses in mice $(89,90)$. Optogenetic stimulation of ARC kisspeptin neurons induced and optogenetic inhibition of ARC kisspeptin neurons suppressed LH pulses in kisspeptin neuron-specific channelrhodopsin- and archaerhodopsin-expressed genemodified mice, respectively $(89,91)$.

GnRH neuronal axons in the median eminence seem to be an action site of kisspeptin for the generation of $\mathrm{GnRH}$ pulses. Immunoelectron microscopy revealed that kisspeptin and $\mathrm{GnRH}$ fibers are closely associated with each other in the internal layer of the median eminence and that few typical synaptic structures were found between kisspeptin and GnRH fibers in rats and goats, suggesting that kisspeptin acts on GnRH axons in a nonsynaptic manner, such as "volume transmission" $(92,93)$. Further, peripheral (not only central) administration of kisspeptin successfully induced $\mathrm{GnRH} /$ gonadotropin release in mammals including rodents $(53,62,64,94)$, ruminants $(46,95)$, and primates $(63,96)$. This may be an advantage for therapeutic use of kisspeptin or its analogs in humans and domestic animals (97-99). Furthermore, GnRH neuronal cell bodies also seem to be an action site of ARC kisspeptin neurons because a retrograde tracing study revealed the projection of ARC kisspeptin neurons to the POA in mice (100) and confocal microscopy revealed contacts of kisspeptin fibers from the ARC population to $\mathrm{GnRH}$ neurons in ewes (101).

\section{ROLES OF KISSPEPTIN, NEUROKININ B, AND DYNORPHIN A IN THE MECHANISM CONTROLLING GNRH PULSE GENERATION}

Theoretically, the GnRH pulse generator would consist of neurons that are connected to each other and show 
synchronized neuronal activity. The dense distribution of kisspeptin neuronal cell bodies and fibers in the whole ARC $(54,75)$ may be indicative of a neuronal connection between kisspeptin neurons. Such a dense kisspeptin-kisspeptin neuronal connection may be necessary to synchronize the release of kisspeptin to the GnRH neurons at the median eminence. Importantly, Gpr54 is not found in ARC kisspeptin neurons in mice (66) and rats (68). Further, electrophysiology or MUA technology revealed that kisspeptin itself unlikely affects the activity of kisspeptin neurons in mice (102), rats (94), and goats (46), suggesting that other neuropeptide(s) may participate to synchronize the kisspeptin neuronal activity.

It is noteworthy that both neurokinin B and dynorphin A are co-localized in a majority of ARC kisspeptin neurons (therefore called KNDy neurons) in several mammalian species including rodents (7-11), ruminants (12-14), and primates $(15,16)$. Neurokinin B is one of the tachykinin family peptides, that are characterized by the presence of the common C-terminal amino acid sequence Phe-X-Gly-Leu-Met (or Leu)-amide (103) (Figure 1B). Among the tachykinin families, substance $\mathrm{P}$, neurokinin A (both of which are cleaved from the same prepropeptide coded by TAC1 gene in humans), and neurokinin $\mathrm{B}$ (which is cleaved from separate prepropeptide coded by TAC3 gene) have been well-investigated, and the amino acid sequences of these peptides are identical in all mammalian species examined to date (103). There are three types of GPCRs for the tachykinins, denoted as NK1, NK2, and NK3 receptors. These receptors are recognized with moderate selectivity by endogenous tachykinins. Neurokinin B was reported to preferentially bind to the NK3 receptor, a Gq-coupled stimulatory GPCR (103). Neurokinin B previously attracted attention as a mediator for the hot flushes in postmenopausal women, who show ovarian steroid hyposecretion and gonadotropin hypersecretion (104). Importantly, inactivating mutations of the TAC3 or TACR3 (encoding the NK3 receptor) gene lead to hypogonadotropic hypogonadism in humans (105, 106), suggesting the importance of neurokinin B-NK3R signaling in human reproduction.

Dynorphin A is a family of endogenous opioid peptides characterized by the presence of the common $\mathrm{N}$-terminal amino acid sequence Tyr-Gly-Gly-Phe-Leu (or Met) (107) (Figure 1C). There are three major endogenous opioids, such as $\beta$-endorphin, enkephalin, and dynorphin $\mathrm{A}$, which are mainly cleaved from the separate prepropeptides encoded by $P O M C$, $P E N K$, and PDYN, respectively. Major corresponding receptors for $\beta$-endorphin, enkephalin, and dynorphin A are suggested to be $\mu$-opioid, $\delta$-opioid, and $\kappa$-opioid receptors, respectively, and the receptors are known as Gi-coupled inhibitory GPCRs (107). Dynorphin A was previously reported to be involved in negative feedback action of progesterone on $\mathrm{GnRH}$ pulse generation in ewes $(108,109)$.

Goodman and colleagues first found that neurokinin B and dynorphin A are largely co-localized in a single population of ARC neurons in ewes by immunohistochemistry for these peptides (110), and then uncovered that kisspeptin is also expressed in the same neuronal population (12). The co-localization of neurokinin $\mathrm{B}$ and dynorphin $\mathrm{A}$ in the ARC kisspeptin neurons were validated in several mammalian species such as goats (13), heifers $(14)$, rats $(9,10)$, mice $(7,8,11)$, and rhesus monkeys $(15,16)$ as summarized in Table 1. Co-localization of kisspeptin and neurokinin B was also found in humans (111-114) (Table 2), whereas few dynorphin A immunoreactivity was detected in the ARC kisspeptin/ neurokinin B neurons in humans (112). Furthermore, NK3 receptors were found in a majority of rodent and ovine ARC KNDy neurons $(7,8,11,115,116)$ and $\kappa$-opioid receptors were found in a majority of rat and ovine KNDy neurons and in a part of mouse KNDy neurons $(7,8,11,115,117,118)$ (Table 3). These findings suggest that the ARC KNDy neurons communicate with each other by neurokinin B-NK3 receptor signaling and dynorphin $\mathrm{A}-\kappa$-opioid receptor signaling in an autocrine/paracrine manner. The species and sex differences in terms of the co-expressing rates of KNDy peptides and their receptors may imply the redundancy of KNDy neurons to maintain reproductive function in mammals as discussed later.

Figure 2 shows a schematic illustration of the hypothesis explaining the mechanism controlling $\mathrm{GnRH}$ pulse generation. The current most plausible interpretation is that neurokinin $\mathrm{B}$ initiates and/or accelerates synchronized KNDy neuronal activity via stimulatory Gq-coupled NK3 receptors to release kisspeptin that stimulates $\mathrm{GnRH}$ release via stimulatory Gqcoupled GPR54 expressed in GnRH neurons, and that dynorphin A released from KNDy neurons then terminates KNDy neuronal activity via inhibitory Gi-coupled $\kappa$-opioid receptors. Indeed, a central administration of neurokinin $\mathrm{B}$ facilitated the frequency of the MUA volley, which is corresponding the $\mathrm{GnRH}$ pulse generator activity, and the frequency was lowered by a central administration of dynorphin $A$ and increased by norbinaltorphimine (nor-BNI), a $\kappa$-opioid receptor antagonist, in female goats (13). Peripheral administrations of PF-4455242, another $\kappa$-opioid receptor antagonist, facilitated and SB223412, an NK3 receptor antagonist, suppressed LH pulses in female goats $(119,120)$. Similarly, a central administration of neurokinin B or nor-BNI facilitated and SB222200, another NK3 receptor antagonist, suppressed LH pulses in ewes (121). In addition, neurokinin $\mathrm{B}$ and senktide, an NK3 receptor agonist, increased the firing frequency of a majority of male mouse KNDy neurons $(8,102)$ and dynorphin A and U50-488, a K-opioid receptor agonist, decreased the firing frequency of all the KNDy neurons tested (102). Taken together, it is most likely that neurokinin B serves as a stimulatory signal for ARC KNDy neurons and dynorphin A serves as an inhibitory signal for the neurons, leading to the synchronized pulsatile pattern of the KNDy neuronal activity to generate $\mathrm{GnRH}$ pulse.

\section{DIRECT EVIDENCE THAT KNDY NEURONS AS THE GNRH PULSE GENERATOR}

As we mentioned above, circumstantial evidence accumulated in the last 15 years suggests that kisspeptin, neurokinin $\mathrm{B}$, and 
A Kisspeptin \begin{tabular}{c} 
Humans \\
\cline { 2 - 6 } (Q15726)
\end{tabular}

'GTSLSPPPESSGSPQQPGLSAPHSRQIPAPQGAVLVQREKDLPNYNWNSFGLRF-NH

\begin{tabular}{r|cccc|} 
Mice & 1 & 1920 & 6768 & \multicolumn{2}{c}{119120} \\
\cline { 2 - 5 } \\
(Q6YSS4)
\end{tabular}

SSPCPPVEGPAGRQRPLCASRSRLIPAPRGAVLVQREKDLSTYNWNSFGLRY-NH

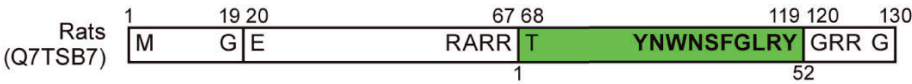

- TSPCPPVENPTGHQRPPCATRSRLIPAPRGSVLVQREKDMSAYNWNSFGLRY-NH

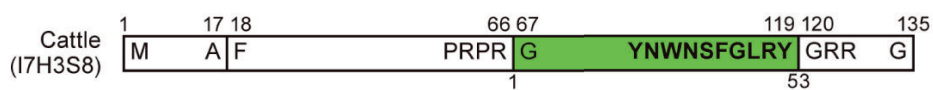

- GAALCPPESSAGPQRLGPCAPRSRLIPSPRGAVLVQREKDVSAYNWNSFGLRY-NH

\begin{tabular}{|c|c|c|c|c|c|}
\hline & 171 & 6667 & & 120 & 135 \\
\hline $\begin{array}{r}\text { Sheep } \\
\text { K7T2X8) }\end{array}$ & $\mathrm{A} \mid \mathrm{B}$ & \begin{tabular}{l|l} 
PRPR & G
\end{tabular} & YNWNSFGLRY & GRR & $\mathrm{G}$ \\
\hline
\end{tabular}

- GAALCPSESSAGPRQPGPCAPRSRLIPAPRGAALVQREKDVSAYNWNSFGLRY-NH

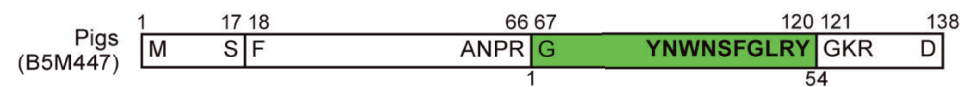

- GTSSCQPPESSSGPQRPGLCTPRSRLIPAPRGAVLVQREKDLSAYNWNSFGLRY-NH 2

B

\begin{tabular}{|c|c|c|c|c|c|c|}
\hline \multirow{2}{*}{ Nerukinin B } & \multirow{2}{*}{$\begin{array}{r}\text { Humans } \\
\text { (Q9UHF0) }\end{array}$} & \multicolumn{2}{|r|}{1617} & 8081 & 9091 & \multirow{2}{*}{$\mathrm{E}^{121}$} \\
\hline & & M & \begin{tabular}{l|l}
$A$ & $Q$ \\
\end{tabular} & PEKR|D & FVGLM $\mid$ GKR & \\
\hline & Mice & $\mathrm{M}$ & $\begin{array}{l}2021 \\
G / A\end{array}$ & $\frac{8182}{\text { PQKR|D }}$ & \begin{tabular}{l|l}
9192 \\
FVGLM
\end{tabular} & \\
\hline & $(135090)$ & 1 & 2021 & 8182 & 9192 & 16 \\
\hline & $\begin{array}{r}\text { Rats } \\
(\mathrm{P} 08435)\end{array}$ & $\mathrm{M}$ & \begin{tabular}{l|l}
$G$ & $A$ \\
\end{tabular} & \begin{tabular}{l|l} 
PQKR & $D$ \\
\end{tabular} & \begin{tabular}{l|c|} 
FVGLM & GKR \\
\end{tabular} & \\
\hline & & -5 & 2021 & 8586 & 9596 & 126 \\
\hline & $\begin{array}{r}\text { Cattle } \\
\text { (P08858) }\end{array}$ & $\mathrm{M}$ & \begin{tabular}{l|l}
$\mathrm{G}$ & $\mathrm{A}$ \\
\end{tabular} & $\begin{array}{l}\text { PQKR } \\
\end{array}$ & \begin{tabular}{l|l|} 
FVGLM & GKR \\
\end{tabular} & $\mathrm{E}$ \\
\hline & Sheep & 1 & 2021 & 8586 & 9596 & 126 \\
\hline & (W5PDI7) & $\mathrm{M}$ & \begin{tabular}{l|l}
$G$ & $A$ \\
\end{tabular} & $\begin{array}{l}\text { PQKR } \\
\end{array}$ & \begin{tabular}{l|l|} 
FVGLM & GKR \\
\end{tabular} & $\mathrm{E}$ \\
\hline & Pigs & -1 & 2021 & 8586 & 9596 & 126 \\
\hline & (P67934) & $\mathrm{M}$ & G $\mid A$ & PQKR|D & \begin{tabular}{l|l|l|l} 
FVGLR \\
\end{tabular} & $\mathrm{E}$ \\
\hline
\end{tabular}

C

\begin{tabular}{|c|c|c|c|c|c|}
\hline \multirow[t]{11}{*}{ Dynorphin A } & \multirow{2}{*}{$\begin{array}{c}\text { Humans } \\
\text { (P01213) }\end{array}$} & \multicolumn{2}{|r|}{2021} & $206207 \quad 223224$ & 254 \\
\hline & & 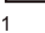 & 2122 & 201202 & 248 \\
\hline & $\begin{array}{r}\text { Mice } \\
(\mathrm{O} 35417)\end{array}$ & $\mathrm{M}$ & $\mathrm{A} \mid \mathrm{D}$ & \begin{tabular}{l|l|l|l} 
LYKR & YGGFL & $\mathrm{Q}$ & $\mathrm{KR}$ \\
\end{tabular} & v \\
\hline & & - & 2122 & 218219 & 248 \\
\hline & $\begin{array}{r}\text { Rats } \\
\text { (P06300) }\end{array}$ & $\mathrm{M}$ & $A \mid D$ & \begin{tabular}{l|l|l|l} 
LYKR & YGGFL & Q & KR \\
\end{tabular} & v \\
\hline & & 1 & 2021 & 227,228 & 258 \\
\hline & $\begin{array}{r}\text { Cattle } \\
\text { (Q95104) }\end{array}$ & $\mathrm{M}$ & \begin{tabular}{l|l}
$A$ & $D$ \\
\end{tabular} & \begin{tabular}{l|ll|l|} 
LYKR & YGGFL & Q & KR \\
\end{tabular} & $\mathrm{v}$ \\
\hline & & 1 & 2021 & 227228 & 258 \\
\hline & $\begin{array}{r}\text { Sheep } \\
\text { (L7PA78) }\end{array}$ & $\mathrm{M}$ & \begin{tabular}{l|l|l}
$A$ & $D$ \\
\end{tabular} & \begin{tabular}{l|ll|l} 
LYKR & YGGFL & $Q$ & KR \\
\end{tabular} & $\mathrm{V}$ \\
\hline & & $\sqrt{5}$ & 2021 & 225226 & 256 \\
\hline & (P01214) & $\mathrm{M}$ & $A \mid D$ & \begin{tabular}{c|cc|c|} 
LYKR & YGGFL & Q & KR \\
\end{tabular} & $\mathrm{V}$ \\
\hline
\end{tabular}

FIGURE 1 | Schematic illustration of kisspeptin, neurokinin B, dynorphin A, and their precursors in humans, mice, rats, cattle, sheep, and pigs based on the previous reports $(43,45,47,49)$ and UniProtKB (https://www.uniprot.org/uniprot/). The precursors comprise a signal peptide in the N-terminal. (A) Kisspeptin consists of 52 or 54 amino acids cleaved from the precursors and the C-terminal is amidated. The C-terminal 10-amino acids (Kp-10) are identical among mice, rats, cattle, sheep, and pigs. Note that C-terminal tyrosine is replaced with phenylalanine in humans. (B) Neurokinin B consists of 10 amino acids cleaved from the precursors and the C-terminal is amidated. The amino acid sequence of neurokinin B is identical among humans, mice, rats, cattle, sheep, and pigs. The C-terminal amino acid sequence Phe-X-Gly-Leu-Met (or Leu)-amide is commonly found in tachykinin family peptides. (C) Dynorphin A consists of 17 amino acids cleaved from their precursors. The amino acid sequence of dynorphin A is identical among mice, rats, cattle, sheep, and pigs. The N-terminal amino acid sequence Tyr-Gly-GlyPhe-Leu (or Met) are commonly found in endogenous opioid peptides. 
TABLE 1 | Co-expression \% of neurokinin B or dynorphin A in the arcuate kisspeptin neurons in ruminants, rodents, and rhesus monkeys.

\begin{tabular}{|c|c|c|c|c|c|}
\hline Species & Sexes and treatments & NKB/Kp & Dyn/Kp & Methods & Reference no. and authors \\
\hline \multirow[t]{2}{*}{ Sheep } & Female (OVX+E2) & - & $94 \%$ & $\mathrm{IHC}$ & (12), Goodman et al., 2007 \\
\hline & Female (Ovary intact) ${ }^{1}$ & $80.4 \%$ & - & $\mathrm{IHC}$ & (12), Goodman et al., 2007 \\
\hline Goats & Female (OVX) & $99.5 \%$ & $78.0 \%$ & $\mathrm{IHC}$ & (13), Wakabayashi et al., 2010 \\
\hline Cattle & Female (Ovary intact) $)^{2}$ & almost all ${ }^{3}$ & $>$ half $^{3}$ & $\mathrm{IHC}$ & (14), Hassaneen et al., 2016 \\
\hline \multirow[t]{2}{*}{ Rats } & Female (OVX) & $97 \%$ & - & $\mathrm{IHC}$ & (9), True et al., 2011 \\
\hline & Female $(\mathrm{OVX}+\mathrm{E} 2)$ & majority ${ }^{4}$ & majority $^{4}$ & $\mathrm{IHC}$ & (10), Murakawa et al., 2016 \\
\hline \multirow[t]{3}{*}{ Mice } & Female (OVX/OVX+E2) & $90 \%$ & $92 \%$ & $\mathrm{ISH}$ & (7), Navarro et al., 2009 \\
\hline & Male (Cast/Cast+T) & $94 \%$ & $86 \%$ & $\mathrm{ISH}$ & (8), Navarro et al., 2011 \\
\hline & Female $(\mathrm{OVX})^{5}$ & $100 \%$ & $100 \%$ & Pooled cell PCR & (11), Ikegami et al., 2017 \\
\hline \multirow[t]{2}{*}{ Rhesus monkeys } & Male (Cast) & $40-60 \%$ & - & $\mathrm{IHC}$ & (15), Ramaswamy et al., 2010 \\
\hline & Female (OVX) & - & $7.3 \%$ & $\mathrm{IHC}$ & (16), True et al., 2017 \\
\hline
\end{tabular}

Cast, castration; Dyn, dynorphin A; E2, estradiol-17ß; Kp, kisspeptin; NKB, neurokinin B; OVX, ovariectomy; T, testosterone.

${ }^{1}$ Data were collected from ewes at the luteal, follicular, and estrous stages.

${ }^{2}$ Data were collected from heifers at the luteal and follicular stages.

${ }^{3}$ Data were not shown as percentage.

${ }^{4}$ Data were not shown as percentage.

${ }^{5}$ Data were collected from Kiss 1-GFP transgenic mice.

dynorphin A in KNDy neurons play key roles in controlling pulsatile $\mathrm{GnRH}$ release in female mammals including rodents $(58,89,91)$ and ruminants $(13,46,121,122)$. However, no direct evidence proving the role of KNDy neurons as the GnRH pulse generator had been provided yet because gene-modified mice and rats lack Kiss1 expression in both two populations of hypothalamic kisspeptin neurons as well as extra-hypothalamic and peripheral kisspeptin-producing cells. For example, we previously generated global Kiss 1 knockout rats to demonstrate the indispensable role of kisspeptin in both pulsatile and surgemode GnRH/gonadotropin release (58). The global Kiss1 knockout rats clearly reproduced the hypogonadal phenotypes of human and mouse models carrying KISS1/Kiss1 or GPR54/ Gpr54 mutations such as pubertal failure and atrophic gonads in both sexes. Importantly, the Kiss1 knockout rats exhibited a complete suppression of pulsatile $\mathrm{LH}$ release even after gonadectomy in both sexes, suggesting that kisspeptin neurons serve as the $\mathrm{GnRH}$ pulse generation in both sexes. In addition, global Kiss1 knockout female rats exhibited no LH surge when animals were treated with preovulatory levels of estradiol-17 $\beta$.

To prove that KNDy neurons serve as the GnRH pulse generator, we rescued KNDy neurons by infecting viral vectors expressing Kiss 1 mRNA targeted into the ARC Tac3-expressing neurons in global Kiss 1 knockout female rats (123). Pulsatile LH release was recovered in KNDy-rescued rats in which $20-50 \%$ ARC Tac3-expressing neurons exhibited Kiss 1 expression. The profiles of $\mathrm{LH}$ pulses are largely dependent on the rescue rates of KNDy neurons, indicating that the rescue of KNDy neurons, but not Kiss 1 transfection outside of ARC Tac3-expressing neurons, could recover LH pulses in global Kiss1 knockout female rats. Further, rescuing KNDy neurons could recover folliculogenesis, but not ovulation, suggesting that KNDy neurons are largely responsible for $\mathrm{GnRH} / \mathrm{LH}$ pulse generation but not surge generation. To confirm the notion obtained by the KNDy rescue experiment, we evaluated the effect of conditional ARC Kiss1 knockout on GnRH pulse generation in newly generated Kiss1-floxed rats. By using the Cre-loxP system, we engineered conditional ARC Kiss1 knockout rats (123). Pulsatile LH release was completely suppressed in conditional ARC Kiss 1 knockout female rats in which $>90 \%$ Kiss1-expressing cells disappeared in the ARC.

The finding that $20 \%$ of KNDy neurons are enough to maintain GnRH pulses and folliculogenesis in the rat suggests the functional redundancy of the KNDy neuronal population. The notion of redundancy is also supported by a previous study showing that gene-modified mice bearing $<5 \%$ Kiss 1 expression still exhibited puberty and fertility in both sexes (124). To date, little is known the functional redundancy of the KNDy neurons in non-rodent mammalian species.

It should be noted that the previous immunohistochemical studies showed co-localization of NK3 receptor in a number of GnRH fibers in rats (125) and $\kappa$-opioid receptor in a majority of GnRH cell bodies in rats and ewes $(118,126)$. These findings imply that neurokinin B and dynorphin A may also directly acts on $\mathrm{GnRH}$ neurons to control GnRH release. Nevertheless, it is unlikely that neurokinin B and/or dynorphin A derived from KNDy neurons directly act on GnRH neurons to participate in GnRH pulse generation. This is because plasma LH/FSH levels

TABLE 2 | Co-expression \% of kisspeptin and neurokinin B in the arcuate nucleus of humans.

\begin{tabular}{|c|c|c|c|c|c|c|}
\hline Species & Sexes & Ages & NKB/Kp & Kp/NKB & Methods & Reference no. and authors \\
\hline \multirow[t]{5}{*}{ Humans } & Female & 27-74 years old & $77.0 \%$ & $95 \%$ & $\mathrm{IHC}$ & (111), Hrabovszky et al., 2010 \\
\hline & Male & Young (21-37 years old) & $75.2 \%$ & $32.9 \%$ & $\mathrm{IHC}$ & (112), Hrabovszky et al., 2012 \\
\hline & Male & Young (21-49 years old) & $72.7 \%$ & $35.8 \%$ & $\mathrm{HC}$ & (113), Molnar et al., 2012 \\
\hline & Male & Aged (50-78 years old) & $77.9 \%$ & $68.1 \%$ & $\mathrm{HCC}$ & (113), Molnar et al., 2012 \\
\hline & Female & Postmenopausal (64-90 years old) & $78.4 \%$ & $66.5 \%$ & $\mathrm{HCC}$ & (114), Skrapits et al., 2014 \\
\hline
\end{tabular}


TABLE 3 | Co-expression \% of NK3 receptors or $\kappa$-opioid receptors in the arcuate kisspeptin/neurokinin B neurons.

\begin{tabular}{|c|c|c|c|c|c|c|}
\hline Species & Sexes and treatments & NK3R & KOR & Targets & Methods & Reference no. and authors \\
\hline \multirow[t]{3}{*}{ Sheep } & Female (Ovary intact $)^{1}$ & $64 \%$ & - & NKB & $\mathrm{IHC}$ & (116), Amstalden, et al., 2010 \\
\hline & Female (Ovary intact) ${ }^{1}$ & - & $97.8 \%$ & $\mathrm{Kp}$ & $\mathrm{HC}$ & (118), Weems et al., 2016 \\
\hline & Female (Ovary intact $)^{1}$ & - & $93.5 \%$ & NKB & $\mathrm{IHC}$ & (118), Weems et al., 2016 \\
\hline Rats & Female (OVX+E2) & - & $62 \%$ & $K p$ & $\mathrm{ISH}$ & (117), Tsuchida et al., 2020 \\
\hline \multirow[t]{5}{*}{ Mice } & Female (OVX/OVX+E2) & $96 \%$ & $20 \%$ & $\mathrm{Kp}$ & $\mathrm{ISH}$ & (7), Navarro et al., 2009 \\
\hline & Male (Cast/Cast+T) & $76 \%$ & $6 \%$ & $\mathrm{Kp}$ & $\mathrm{ISH}$ & (8), Navarro et al., 2011 \\
\hline & Male (Testis intact) ${ }^{2}$ & $35 \%$ & $41 \%$ & NKB & Single-cell PCR & (115), Ruka et al., 2013 \\
\hline & Male $(\text { Cast })^{2}$ & $86 \%$ & $19 \%$ & NKB & Single-cell PCR & (115), Ruka et al., 2013 \\
\hline & Female $(O V X)^{3}$ & $83 \%$ & $33 \%$ & $\mathrm{Kp}$ & Pooled cell PCR & (11), Ikegami et al., 2017 \\
\hline
\end{tabular}

Cast, castration; E2, estradiol-17ß; Kp, kisspeptin; KOR, $\kappa$-opioid receptors; NK3R, NK3 receptors; NKB, neurokinin B; OVX, ovariectomy; T, testosterone.

${ }^{1}$ Data were collected from ewes at the luteal stage.

${ }^{2}$ Data were collected from Tac2-GFP transgenic mice.

${ }^{3}$ Data were collected from Kiss 1-GFP transgenic mice.

were undetectable in global Kiss1 knockout rats (58), in which Tac3 and Pdyn gene were abundantly expressed in the ARC as shown in wild-type female rats. Further, Kiss 1 rescue into the ARC Tac3-expressing cells but not out of the Tac3-expressing cells rescued LH pulses in the global Kiss1 knockout female rats (123). These findings indicate that ARC neurokinin B/ dynorphin A neurons without Kiss1 could not drive GnRH/
LH pulse generation. In this context, non-KNDy neurokinin B or dynorphin A neurons may directly project $\mathrm{GnRH}$ neurons and control/modulate $\mathrm{GnRH}$ and consequent gonadotropin release. Supportedly, our recent study suggested that the dynorphin neurons derived from the hypothalamic paraventricular nucleus mediate glucoprivic suppression of LH pulses (117).

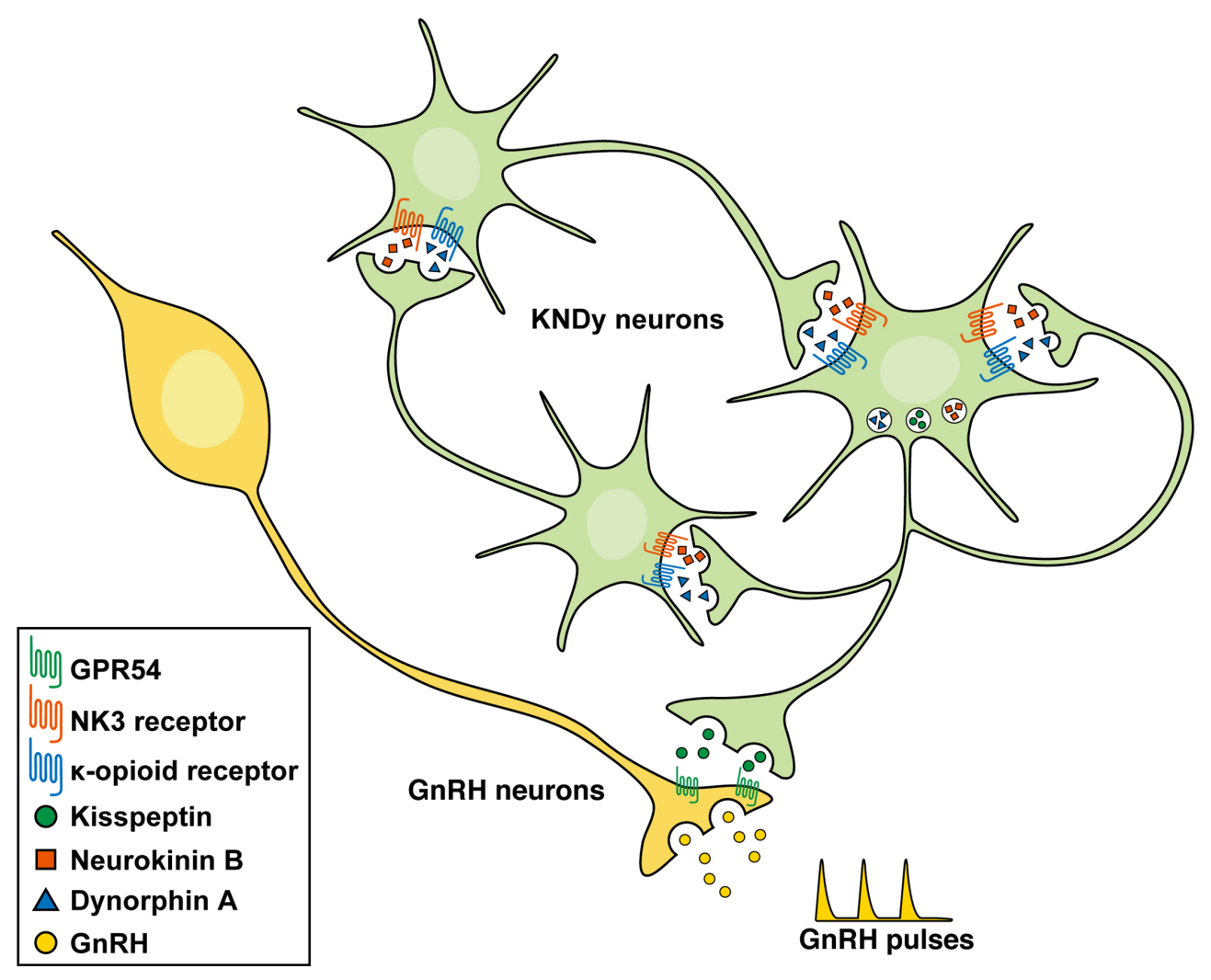

FIGURE 2 | Schematic illustration of the hypothetical mechanism controlling gonadotropin-releasing hormone (GnRH) pulse generation in mammals. Neurokinin B initiates and/or accelerates synchronized KNDy neuronal activity via stimulatory Gq-coupled NK3 receptors to release kisspeptin that stimulates GnRH release via stimulatory Gq-coupled GPR54 expressed in GnRH neurons. Dynorphin A released from KNDy neurons then terminates KNDy neuronal activity via inhibitory Gicoupled k-opioid receptors. 


\section{CONCLUSIONS, UNANSWERED QUESTIONS, AND FUTURE ASPECTS}

Kisspeptin discovery in the early 2000s and its subsequent studies have provided a breakthrough in our understanding of the brain mechanism underlying reproduction in mammals along with the rediscovery of the critical roles of neurokinin $\mathrm{B}$, a tachykinin, and dynorphin $\mathrm{A}$, an endogenous opioid peptide. We now postulate that KNDy neurons act as an intrinsic source of the GnRH pulse generator, in which neurokinin B serves as a stimulatory signal, dynorphin A serves as an inhibitory signal, and kisspeptin serve as an output signal of KNDy neurons that drive $\mathrm{GnRH}$ release from the GnRH neurons. There are, however, still some unanswered questions. For example, there are reportedly species differences in neurokinin B signaling in KNDy neurons: The NK3 receptor antagonist SB223412 potently inhibited gonadotropin and testosterone release in male dogs (127), on the other hand, CS-003, a triple tachykinin receptor antagonist, was needed to inhibit LH secretion in male and female rats (128). Similarly, electrophysiology revealed that three tachykinin receptors were needed to be antagonized to prevent the stimulatory action of $\mathrm{NKB}$ on male mouse KNDy neurons in vitro (102). There are also species differences in terms of the co-expressing rates of dynorphin $\mathrm{A}$ and $\kappa$-opioid receptors in KNDy neurons as described above. Further, the sex differences in the number of ARC kisspeptin/neurokinin B neurons were reported in humans: males have fewer kisspeptin- and neurokinin B-positive cells in the ARC than females (111, 129). The sex differences could be caused by feedback from different endogenous steroids in gonad-intact human subjects as reviewed elsewhere $(122,130)$. Indeed, previous studies showed the increases in KISS1 and TAC3 expression in the ARC of postmenopausal women compared to premenopausal women

\section{REFERENCES}

1. Elphick MR, Mirabeau O, Larhammar D. Evolution of Neuropeptide Signalling Systems. J Exp Biol (2018) 221:jeb151092. doi: 10.1242/jeb.151092

2. Grimmelikhuijzen CJ, Hauser F. Mini-Review: The Evolution of Neuropeptide Signaling. Regul Pept (2012) 177 Suppl:S6-9. doi: 10.1016/ j.regpep.2012.05.001

3. Takahashi T. Comparative Aspects of Structure and Function of Cnidarian Neuropeptides. Front Endocrinol (2020) 11:339. doi: 10.3389/fendo.2020.00339

4. Vaudry H, Seong JY. Neuropeptide GPCRs in Neuroendocrinology. Front Endocrinol (2014) 5:41. doi: 10.3389/fendo.2014.00041

5. Dixon RA, Kobilka BK, Strader DJ, Benovic JL, Dohlman HG, Frielle T, et al. Cloning of the Gene and cDNA for Mammalian Beta-Adrenergic Receptor and Homology With Rhodopsin. Nature (1986) 321:75-9. doi: 10.1038/ $321075 \mathrm{a} 0$

6. Hauser AS, Gloriam DE, Brauner-Osborne H, Foster SR. Novel Approaches Leading Towards Peptide GPCR De-Orphanisation. Br J Pharmacol (2020) 177:961-8. doi: 10.1111/bph.14950

7. Navarro VM, Gottsch ML, Chavkin C, Okamura H, Clifton DK, Steiner RA. Regulation of Gonadotropin-Releasing Hormone Secretion by Kisspeptin/ Dynorphin/Neurokinin B Neurons in the Arcuate Nucleus of the Mouse. J Neurosci (2009) 29:11859-66. doi: 10.1523/JNEUROSCI.1569-09.2009

8. Navarro VM, Gottsch ML, Wu M, Garcia-Galiano D, Hobbs SJ, Bosch MA, et al. Regulation of NKB Pathways and Their Roles in the Control of Kiss1 Neurons in the Arcuate Nucleus of the Male Mouse. Endocrinology (2011) 152:4265-75. doi: 10.1210/en.2011-1143
(84, 104). Further studies are warranted on how neurokinin B and dynorphin A orchestrate the synchronized activity of KNDy neurons and GnRH pulses in mammals and the significance behind the species and sex differences to contribute to future therapeutic approaches in both humans and domestic animals suffering from reproductive disorders.

\section{AUTHOR CONTRIBUTIONS}

YU and HirT collected the information and wrote the manuscript. NI designed the pictures and critically revised the manuscript. $\mathrm{MN}$ and HitT collected the information and critically revised the manuscript. All authors contributed to the article and approved the submitted version.

\section{FUNDING}

The present study was supported in part by JSPS KAKENHI Grant Numbers 18H03973, 21K19186, and 21H05031 (to HirT), $19 \mathrm{H} 03103$ (to NI), 20H03127 (to YU).

\section{ACKNOWLEDGMENTS}

We respectfully acknowledge the contributions of the late Professor Kei-ichiro Maeda, Ph.D., D.V.M., of The University of Tokyo, who suddenly passed away in February 2018. His leadership, insight, and invaluable ideas contributed greatly to our original studies reviewed in this article. We wish to thank Dr. Nicola Skoulding for editorial assistance.

9. True C, Kirigiti M, Ciofi P, Grove KL, Smith MS. Characterisation of Arcuate Nucleus Kisspeptin/Neurokinin B Neuronal Projections and Regulation During Lactation in the Rat. J Neuroendocrinol (2011) 23:5264. doi: 10.1111/j.1365-2826.2010.02076.x

10. Murakawa H, Iwata K, Takeshita T, Ozawa H. Immunoelectron Microscopic Observation of the Subcellular Localization of Kisspeptin, Neurokinin B and Dynorphin A in KNDy Neurons in the Arcuate Nucleus of the Female Rat. Neurosci Lett (2016) 612:161-6. doi: 10.1016/j.neulet.2015.12.008

11. Ikegami K, Minabe S, Ieda N, Goto T, Sugimoto A, Nakamura S, et al. Evidence of Involvement of Neurone-Glia/Neurone-Neurone Communications via Gap Junctions in Synchronised Activity of KNDy Neurones. J Neuroendocrinol (2017) 29:1-14. doi: 10.1111/jne.12480

12. Goodman RL, Lehman MN, Smith JT, Coolen LM, de Oliveira CV, Jafarzadehshirazi MR, et al. Kisspeptin Neurons in the Arcuate Nucleus of the Ewe Express Both Dynorphin A and Neurokinin B. Endocrinology (2007) 148:5752-60. doi: 10.1210/en.2007-0961

13. Wakabayashi Y, Nakada T, Murata K, Ohkura S, Mogi K, Navarro VM, et al. Neurokinin B and Dynorphin A in Kisspeptin Neurons of the Arcuate Nucleus Participate in Generation of Periodic Oscillation of Neural Activity Driving Pulsatile Gonadotropin-Releasing Hormone Secretion in the Goat. J Neurosci (2010) 30:3124-32. doi: 10.1523/JNEUROSCI.5848-09.2010

14. Hassaneen ASA, Naniwa Y, Suetomi Y, Matsuyama S, Kimura K, Ieda N, et al. Immunohistochemical Characterization of the Arcuate Kisspeptin/ Neurokinin B/dynorphin (KNDy) and Preoptic Kisspeptin Neuronal Populations in the Hypothalamus During the Estrous Cycle in Heifers. J Reprod Dev (2016) 62:471-7. doi: 10.1262/jrd.2016-075 
15. Ramaswamy S, Seminara SB, Ali B, Ciofi P, Amin NA, Plant TM. Neurokinin B Stimulates GnRH Release in the Male Monkey (Macaca Mulatta) and Is Colocalized With Kisspeptin in the Arcuate Nucleus. Endocrinology (2010) 151:4494-503. doi: 10.1210/en.2010-0223

16. True C, Takahashi D, Kirigiti M, Lindsley SR, Moctezuma C, Arik A, et al. Arcuate Nucleus Neuropeptide Coexpression and Connections to Gonadotrophin-Releasing Hormone Neurones in the Female Rhesus Macaque. J Neuroendocrinol (2017) 29:1-15. doi: 10.1111/jne.12491

17. Smith PE. Ablation and Transplantation of the Hypophysis in the Rat. Anat $\operatorname{Rec}(1926)$ 32:15-6.

18. Evans HM, Long JA. Characteristic Effects Upon Growth, Oestrus and Ovulation Induced by the Intraperitoneal Administration of Fresh Anterior Hypophyseal Substance. Proc Natl Acad Sci USA (1922) 8:38-9. doi: 10.1073/ pnas.8.3.38

19. Hamburger C. Historical Introduction. In: GEW Wolstenholme and J Knight, editors. Gonadotropins: Physiochemical and Immunological Properties. London W.I.: J. \& A. Churchill Ltd. (1966). p. 2-10.

20. Fevold HL, Hisaw FL, Leonard SL. The Gonad Stimulating and the Luteinizing Hormones of the Anterior Lobe of the Hypophesis. Am J Physiol (1931) 97:291-301. doi: 10.1152/ajplegacy.1931.97.2.291

21. Schally AV. Use of GnRH in Preference to LH-RH Terminology in Scientific Papers. Hum Reprod (2000) 15:2059-61. doi: 10.1093/humrep/15.9.2059

22. Harris GW, Jacobsohn D. Functional Grafts of the Anterior Pituitary Gland. Proc R Soc Lond B Biol Sci (1952) 139:263-76. doi: 10.1098/rspb.1952.0011

23. Matsuo H, Baba Y, Nair RM, Arimura A, Schally AV. Structure of the Porcine LH- and FSH-Releasing Hormone. I. The Proposed Amino Acid Sequence. Biochem Biophys Res Commun (1971) 43:1334-9. doi: 10.1016/ S0006-291X(71)80019-0

24. Amoss M, Burgus R, Blackwell R, Vale W, Fellows R, Guillemin R. Purification, Amino Acid Composition and N-Terminus of the Hypothalamic Luteinizing Hormone Releasing Factor (LRF) of Ovine Origin. Biochem Biophys Res Commun (1971) 44:205-10. doi: 10.1016/ S0006-291X(71)80179-1

25. Dierschke DJ, Bhattacharya AN, Atkinson LE, Knobil E. Circhoral Oscillations of Plasma LH Levels in the Ovariectomized Rhesus Monkey. Endocrinology (1970) 87:850-3. doi: 10.1210/endo-87-5-850

26. Monroe SE, Atkinson LE, Knobil E. Patterns of Circulating Luteinizing Hormone and Their Relation to Plasma Progesterone Levels During the Menstrual Cycle of the Rhesus Monkey. Endocrinology (1970) 87:453-5. doi: 10.1210/endo-87-3-453

27. Belchetz PE, Plant TM, Nakai Y, Keogh EJ, Knobil E. Hypophysial Responses to Continuous and Intermittent Delivery of Hypothalamic Gonadotropin-Releasing Hormone. Science (1978) 202:631-3. doi: 10.1126/science. 100883

28. Filicori M, Cognigni GE. Ovulation Induction With Pulsatile Gonadotropin Releasing Hormone: Missing in Action. Fertil Steril (2018) 109:621-2. doi: 10.1016/j.fertnstert.2018.01.023

29. Plosker GL, Brogden RN. Leuprorelin. Drugs (1994) 48:930-67. doi: 10.2165/00003495-199448060-00008

30. Clarke IJ, Cummins JT. The Temporal Relationship Between Gonadotropin Releasing Hormone (GnRH) and Luteinizing Hormone (LH) Secretion in Ovariectomized Ewes. Endocrinology (1982) 111:1737-9. doi: 10.1210/endo111-5-1737

31. Moenter SM, Brand RM, Midgley AR, Karsch FJ. Dynamics of Gonadotropin-Releasing Hormone Release During a Pulse. Endocrinology (1992) 130:503-10. doi: 10.1210/endo.130.1.1727719

32. Lincoln DW, Fraser HM, Lincoln GA, Martin GB, McNeilly AS. Hypothalamic Pulse Generators. Recent Prog Horm Res (1985) 41:369419. doi: 10.1016/B978-0-12-571141-8.50013-5

33. Maeda K-I, Tsukamura H, Ohkura S, Kawakami S, Nagabukuro H, Yokoyama A. The LHRH Pulse Generator: A Mediobasal Hypothalamic Location. Neurosci Biobehav Rev (1995) 19:427-37. doi: 10.1016/0149-7634(94)00069-D

34. Halász B, Pupp L. Hormone Secretion of the Anterior Pituitary Gland After Physical Interruption of All Nervous Pathways to the Hypophysiotrophic Area. Endocrinology (1965) 77:553-62. doi: 10.1210/endo-77-3-553

35. Blake CA, Sawyer CH. Effects of Hypothalamic Deafferentation on the Pulsatile Rhythm in Plasma Concentrations of Luteinizing Hormone in Ovariectomized Rats. Endocrinology (1974) 94:730-6. doi: 10.1210/endo-94-3-730
36. Ohkura S, Tsukamura H, Maeda K-I. Effects of Various Types of Hypothalamic Deafferentation on Luteinizing Hormone Pulses in Ovariectomized Rats. J Neuroendocrinol (1991) 3:503-8. doi: 10.1111/ j.1365-2826.1991.tb00310.x

37. Silverman AJ, Jhamandas J, Renaud LP. Localization of Luteinizing Hormone-Releasing Hormone (LHRH) Neurons That Project to the Median Eminence. J Neurosci (1987) 7:2312-9.

38. Wilson RC, Kesner JS, Kaufman JM, Uemura T, Akema T, Knobil E. Central Electrophysiologic Correlates of Pulsatile Luteinizing Hormone Secretion in the Rhesus Monkey. Neuroendocrinology (1984) 39:256-60. doi: 10.1159/ 000123988

39. Kimura F, Nishihara M, Hiruma H, Funabashi T. Naloxone Increases the Frequency of the Electrical Activity of Luteinizing Hormone-Releasing Hormone Pulse Generator in Long-Term Ovariectomized Rats. Neuroendocrinology (1991) 53:97-102. doi: 10.1159/000125704

40. Nishihara M, Hiruma H, Kimura F. Interactions Between the Noradrenergic and Opioid Peptidergic Systems in Controlling the Electrical Activity of Luteinizing Hormone-Releasing Hormone Pulse Generator in Ovariectomized Rats. Neuroendocrinology (1991) 54:321-6. doi: 10.1159/ 000125909

41. Mori Y, Nishihara M, Tanaka T, Shimizu T, Yamaguchi M, Takeuchi Y, et al. Chronic Recording of Electrophysiological Manifestation of the Hypothalamic Gonadotropin-Releasing Hormone Pulse Generator Activity in the Goat. Neuroendocrinology (1991) 53:392-5. doi: 10.1159/000125746

42. Lee DK, Nguyen T, O’Neill GP, Cheng R, Liu Y, Howard AD, et al. Discovery of a Receptor Related to the Galanin Receptors. FEBS Lett (1999) 446:103-7. doi: 10.1016/S0014-5793(99)00009-5

43. Ohtaki T, Shintani Y, Honda S, Matsumoto H, Hori A, Kanehashi K, et al. Metastasis Suppressor Gene KiSS-1 Encodes Peptide Ligand of a G-ProteinCoupled Receptor. Nature (2001) 411:613-7. doi: 10.1038/35079135

44. Kotani M, Detheux M, Vandenbogaerde A, Communi D, Vanderwinden JM, Le Poul E, et al. The Metastasis Suppressor Gene KiSS-1 Encodes Kisspeptins, the Natural Ligands of the Orphan G Protein-Coupled Receptor GPR54. J Biol Chem (2001) 276:34631-6. doi: 10.1074/jbc.M104847200

45. Terao Y, Kumano S, Takatsu Y, Hattori M, Nishimura A, Ohtaki T, et al. Expression of KiSS-1, A Metastasis Suppressor Gene, in Trophoblast Giant Cells of the Rat Placenta. Biochim Biophys Acta (2004) 1678:102-10. doi: 10.1016/j.bbaexp.2004.02.005

46. Ohkura S, Takase K, Matsuyama S, Mogi K, Ichimaru T, Wakabayashi Y, et al. Gonadotrophin-Releasing Hormone Pulse Generator Activity in the Hypothalamus of the Goat. J Neuroendocrinol (2009) 21:813-21. doi: 10.1111/j.1365-2826.2009.01909.x

47. Tomikawa J, Homma T, Tajima S, Shibata T, Inamoto Y, Takase K, et al. Molecular Characterization and Estrogen Regulation of Hypothalamic KISS1 Gene in the Pig. Biol Reprod (2010) 82:313-9. doi: 10.1095/ biolreprod.109.079863

48. Inoue N, Sasagawa K, Ikai K, Sasaki Y, Tomikawa J, Oishi S, et al. Kisspeptin Neurons Mediate Reflex Ovulation in the Musk Shrew (Suncus Murinus). Proc Natl Acad Sci USA (2011) 108:17527-32. doi: 10.1073/pnas.1113035108

49. Naniwa Y, Nakatsukasa K, Setsuda S, Oishi S, Fujii N, Matsuda F, et al. Effects of Full-Length Kisspeptin Administration on Follicular Development in Japanese Black Beef Cows. J Reprod Dev (2013) 59:588-94. doi: 10.1262/ jrd.2013-064

50. Watanabe Y, Uenoyama Y, Suzuki J, Takase K, Suetomi Y, Ohkura S, et al. Oestrogen-Induced Activation of Preoptic Kisspeptin Neurones May Be Involved in the Luteinizing Hormone Surge in Male and Female Japanese Monkeys. J Neuroendocrinol (2014) 26:909-17. doi: 10.1111/jne.12227

51. de Roux N, Genin E, Carel JC, Matsuda F, Chaussain JL, Milgrom E. Hypogonadotropic Hypogonadism Due to Loss of Function of the KiSS1Derived Peptide Receptor GPR54. Proc Natl Acad Sci USA (2003) 100:10972-6. doi: 10.1073/pnas.1834399100

52. Seminara SB, Messager S, Chatzidaki EE, Thresher RR, Acierno JS Jr, Shagoury JK, et al. The GPR54 Gene as a Regulator of Puberty. N Engl J Med (2003) 349:1614-27. doi: 10.1056/NEJMoa035322

53. Messager S, Chatzidaki EE, Ma D, Hendrick AG, Zahn D, Dixon J, et al. Kisspeptin Directly Stimulates Gonadotropin-Releasing Hormone Release via G Protein-Coupled Receptor 54. Proc Natl Acad Sci USA (2005) 102:1761-6. doi: 10.1073/pnas.0409330102 
54. Kinoshita M, Tsukamura H, Adachi S, Matsui H, Uenoyama Y, Iwata K, et al. Involvement of Central Metastin in the Regulation of Preovulatory Luteinizing Hormone Surge and Estrous Cyclicity in Female Rats. Endocrinology (2005) 146:4431-6. doi: 10.1210/en.2005-0195

55. d'Anglemont de Tassigny X, Fagg LA, Dixon JP, Day K, Leitch HG, Hendrick AG, et al. Hypogonadotropic Hypogonadism in Mice Lacking a Functional Kiss1 Gene. Proc Natl Acad Sci USA (2007) 104:10714-9. doi: 10.1073/pnas.0704114104

56. Lapatto R, Pallais JC, Zhang D, Chan YM, Mahan A, Cerrato F, et al. Kiss $1^{-/-}$ Mice Exhibit More Variable Hypogonadism Than Gpr54-1- Mice. Endocrinology (2007) 148:4927-36. doi: 10.1210/en.2007-0078

57. Chan YM, Broder-Fingert S, Wong KM, Seminara SB. Kisspeptin/Gpr54Independent Gonadotrophin-Releasing Hormone Activity in Kiss1 and Gpr54 Mutant Mice. J Neuroendocrinol (2009) 21:1015-23. doi: 10.1111/ j.1365-2826.2009.01926.x

58. Uenoyama Y, Nakamura S, Hayakawa Y, Ikegami K, Watanabe Y, Deura C, et al. Lack of Pulse and Surge Modes and Glutamatergic Stimulation of LH Release in Kiss1 Knockout Rats. J Neuroendocrinol (2015) 27:187-97. doi: 10.1111/jne.12257

59. Topaloglu AK, Tello JA, Kotan LD, Ozbek MN, Yilmaz MB, Erdogan S, et al. Inactivating KISS1 Mutation and Hypogonadotropic Hypogonadism. N Engl J Med (2012) 366:629-35. doi: 10.1056/NEJMoa1111184

60. Irwig MS, Fraley GS, Smith JT, Acohido BV, Popa SM, Cunningham MJ, et al. Kisspeptin Activation of Gonadotropin Releasing Hormone Neurons and Regulation of KiSS-1 mRNA in the Male Rat. Neuroendocrinology (2004) 80:264-72. doi: 10.1159/000083140

61. Gottsch ML, Cunningham MJ, Smith JT, Popa SM, Acohido BV, Crowley WF, et al. A Role for Kisspeptins in the Regulation of Gonadotropin Secretion in the Mouse. Endocrinology (2004) 145:4073-7. doi: 10.1210/en.2004-0431

62. Pheng V, Uenoyama Y, Homma T, Inamoto Y, Takase K, YoshizawaKumagaye K, et al. Potencies of Centrally- or Peripherally-Injected FullLength Kisspeptin or Its C-Terminal Decapeptide on LH Release in Intact Male Rats. J Reprod Dev (2009) 55:378-82. doi: 10.1262/jrd.20240

63. Shahab M, Mastronardi C, Seminara SB, Crowley WF, Ojeda SR, Plant TM. Increased Hypothalamic GPR54 Signaling: A Potential Mechanism for Initiation of Puberty in Primates. Proc Natl Acad Sci USA (2005) 102:2129-34. doi: 10.1073/pnas.0409822102

64. Matsui H, Takatsu Y, Kumano S, Matsumoto H, Ohtaki T. Peripheral Administration of Metastin Induces Marked Gonadotropin Release and Ovulation in the Rat. Biochem Biophys Res Commun (2004) 320:383-8. doi: 10.1016/j.bbrc.2004.05.185

65. Castellano JM, Navarro VM, Fernandez-Fernandez R, Castano JP, Malagon MM, Aguilar E, et al. Ontogeny and Mechanisms of Action for the Stimulatory Effect of Kisspeptin on Gonadotropin-Releasing Hormone System of the Rat. Mol Cell Endocrinol (2006) 257-258:75-83. doi: 10.1016/j.mce.2006.07.002

66. Herbison AE, de Tassigny X, Doran J, Colledge WH. Distribution and Postnatal Development of Gpr54 Gene Expression in Mouse Brain and Gonadotropin-Releasing Hormone Neurons. Endocrinology (2010) 151:31221. doi: 10.1210/en.2009-0552

67. Han SK, Gottsch ML, Lee KJ, Popa SM, Smith JT, Jakawich SK, et al. Activation of Gonadotropin-Releasing Hormone Neurons by Kisspeptin as a Neuroendocrine Switch for the Onset of Puberty. J Neurosci (2005) 25:11349-56. doi: 10.1523/JNEUROSCI.3328-05.2005

68. Higo S, Honda S, Iijima N, Ozawa H. Mapping of Kisspeptin Receptor mRNA in the Whole Rat Brain and Its Co-Localisation With Oxytocin in the Paraventricular Nucleus. J Neuroendocrinol (2016) 28:10. doi: 10.1111/jne.12356

69. Pielecka-Fortuna J, Chu Z, Moenter SM. Kisspeptin Acts Directly and Indirectly to Increase Gonadotropin-Releasing Hormone Neuron Activity and Its Effects Are Modulated by Estradiol. Endocrinology (2008) 149:197986. doi: 10.1210/en.2007-1365

70. Liu X, Lee K, Herbison AE. Kisspeptin Excites Gonadotropin-Releasing Hormone Neurons Through a Phospholipase C/calcium-Dependent Pathway Regulating Multiple Ion Channels. Endocrinology (2008) 149:4605-14. doi: 10.1210/en.2008-0321

71. Kirilov M, Clarkson J, Liu X, Roa J, Campos P, Porteous R, et al. Dependence of Fertility on Kisspeptin-Gpr54 Signaling at the GnRH Neuron. Nat Commun (2013) 4:2492. doi: 10.1038/ncomms3492
72. Smith JT, Cunningham MJ, Rissman EF, Clifton DK, Steiner RA. Regulation of Kiss1 Gene Expression in the Brain of the Female Mouse. Endocrinology (2005) 146:3686-92. doi: 10.1210/en.2005-0488

73. Clarkson J, Herbison AE. Postnatal Development of Kisspeptin Neurons in Mouse Hypothalamus; Sexual Dimorphism and Projections to Gonadotropin-Releasing Hormone Neurons. Endocrinology (2006) 147:5817-25. doi: 10.1210/en.2006-0787

74. Smith JT, Popa SM, Clifton DK, Hoffman GE, Steiner RA. Kiss1 Neurons in the Forebrain as Central Processors for Generating the Preovulatory Luteinizing Hormone Surge. J Neurosci (2006) 26:6687-94. doi: 10.1523/ JNEUROSCI.1618-06.2006

75. Adachi S, Yamada S, Takatsu Y, Matsui H, Kinoshita M, Takase K, et al. Involvement of Anteroventral Periventricular Metastin/Kisspeptin Neurons in Estrogen Positive Feedback Action on Luteinizing Hormone Release in Female Rats. J Reprod Dev (2007) 53:367-78. doi: 10.1262/jrd.18146

76. Kauffman AS, Gottsch ML, Roa J, Byquist AC, Crown A, Clifton DK, et al. Sexual Differentiation of Kiss1 Gene Expression in the Brain of the Rat. Endocrinology (2007) 148:1774-83. doi: 10.1210/en.2006-1540

77. Takase K, Uenoyama Y, Inoue N, Matsui H, Yamada S, Shimizu M, et al. Possible Role of Oestrogen in Pubertal Increase of Kiss1/kisspeptin Expression in Discrete Hypothalamic Areas of Female Rats. J Neuroendocrinol (2009) 21:527-37. doi: 10.1111/j.1365-2826.2009.01868.x

78. Smith JT, Li Q, Pereira A, Clarke IJ. Kisspeptin Neurons in the Ovine Arcuate Nucleus and Preoptic Area Are Involved in the Preovulatory Luteinizing Hormone Surge. Endocrinology (2009) 150:5530-8. doi: 10.1210/en.2009-0712

79. Matsuda F, Nakatsukasa K, Suetomi Y, Naniwa Y, Ito D, Inoue N, et al. The LH Surge-Generating System Is Functional in Male Goats as in Females: Involvement of Kisspeptin Neurones in the Medial Preoptic Area. J Neuroendocrinol (2015) 27:57-65. doi: 10.1111/jne.12235

80. Estrada KM, Clay CM, Pompolo S, Smith JT, Clarke IJ. Elevated KiSS-1 Expression in the Arcuate Nucleus Prior to the Cyclic Preovulatory Gonadotrophin-Releasing Hormone/Lutenising Hormone Surge in the Ewe Suggests a Stimulatory Role for Kisspeptin in Oestrogen-Positive Feedback. J Neuroendocrinol (2006) 18:806-9. doi: 10.1111/j.1365-2826.2006.01485.x

81. Franceschini I, Lomet D, Cateau M, Delsol G, Tillet Y, Caraty A. Kisspeptin Immunoreactive Cells of the Ovine Preoptic Area and Arcuate Nucleus CoExpress Estrogen Receptor Alpha. Neurosci Lett (2006) 401:225-30. doi: 10.1016/j.neulet.2006.03.039

82. Smith JT, Clay CM, Caraty A, Clarke IJ. KiSS-1 Messenger Ribonucleic Acid Expression in the Hypothalamus of the Ewe Is Regulated by Sex Steroids and Season. Endocrinology (2007) 148:1150-7. doi: 10.1210/en.2006-1435

83. Smith JT, Rao A, Pereira A, Caraty A, Millar RP, Clarke IJ. Kisspeptin Is Present in Ovine Hypophysial Portal Blood But Does Not Increase During the Preovulatory Luteinizing Hormone Surge: Evidence That Gonadotropes Are Not Direct Targets of Kisspeptin In Vivo. Endocrinology (2008) 149:1951-9. doi: 10.1210/en.2007-1425

84. Rometo AM, Krajewski SJ, Voytko ML, Rance NE. Hypertrophy and Increased Kisspeptin Gene Expression in the Hypothalamic Infundibular Nucleus of Postmenopausal Women and Ovariectomized Monkeys. J Clin Endocrinol Metab (2007) 92:2744-50. doi: 10.1210/jc.2007-0553

85. Smith JT, Shahab M, Pereira A, Pau KY, Clarke IJ. Hypothalamic Expression of KISS1 and Gonadotropin Inhibitory Hormone Genes During the Menstrual Cycle of a Non-Human Primate. Biol Reprod (2010) 83:568-77. doi: 10.1095/biolreprod.110.085407

86. Tsukamura H, Maeda K-I, Uenoyama Y. Fetal/perinatal Programming Causing Sexual Dimorphism of the Kisspeptin-GnRH Neuronal Network. In: AE Herbison and TM Plant, editors. The GnRH Neuron and Its Control. Hoboken, NJ: Wiley (2018). p. 43-60.

87. Tsukamura H. Kobayashi Award 2019: The Neuroendocrine Regulation of the Mammalian Reproduction. Gen Comp Endocrinol (2021) 113755. doi: 10.1016/j.ygcen.2021.113755

88. Tsukamura H, Homma T, Tomikawa J, Uenoyama Y, Maeda K-I. Sexual Differentiation of Kisspeptin Neurons Responsible for Sex Difference in Gonadotropin Release in Rats. Ann NY Acad Sci (2010) 1200:95-103. doi: 10.1111/j.1749-6632.2010.05645.x

89. Clarkson J, Han SY, Piet R, McLennan T, Kane GM, Ng J, et al. Definition of the Hypothalamic GnRH Pulse Generator in Mice. Proc Natl Acad Sci USA (2017) 114:E10216-23. doi: 10.1073/pnas.1713897114 
90. Han SY, Kane G, Cheong I, Herbison AE. Characterization of GnRH Pulse Generator Activity in Male Mice Using GCaMP Fiber Photometry. Endocrinology (2019) 160:557-67. doi: 10.1210/en.2018-01047

91. Han SY, McLennan T, Czieselsky K, Herbison AE. Selective Optogenetic Activation of Arcuate Kisspeptin Neurons Generates Pulsatile Luteinizing Hormone Secretion. Proc Natl Acad Sci USA (2015) 112:13109-14. doi: $10.1073 /$ pnas. 1512243112

92. Matsuyama S, Ohkura S, Mogi K, Wakabayashi Y, Mori Y, Tsukamura H, et al. Morphological Evidence for Direct Interaction Between Kisspeptin and Gonadotropin-Releasing Hormone Neurons at the Median Eminence of the Male Goat: An Immunoelectron Microscopic Study. Neuroendocrinology (2011) 94:323-32. doi: 10.1159/000331576

93. Uenoyama $\mathrm{Y}$, Inoue $\mathrm{N}$, Pheng $\mathrm{V}$, Homma $\mathrm{T}$, Takase $\mathrm{K}$, Yamada $\mathrm{S}$, et al. Ultrastructural Evidence of Kisspeptin-Gonadotrophin-Releasing Hormone Interaction in the Median Eminence of Female Rats: Implication of AxoAxonal Regulation of GnRH Release. J Neuroendocrinol (2011) 23:863-70. doi: 10.1111/j.1365-2826.2011.02199.x

94. Kinsey-Jones JS, Li XF, Luckman SM, O’Byrne KT. Effects of Kisspeptin-10 on the Electrophysiological Manifestation of Gonadotropin-Releasing Hormone Pulse Generator Activity in the Female Rat. Endocrinology (2008) 149:1004-8. doi: 10.1210/en.2007-1505

95. Tanaka T, Ohkura S, Wakabayashi K, Okamura H. Effect of Peripherally Administered Kisspeptin-10 on GnRH Neurosecretion Into the Hypophyseal Portal Circulation in Ovariectomized Goat Does. Small Ruminant Res (2012) 105:273-6. doi: 10.1016/j.smallrumres.2012.01.007

96. Dhillo WS, Chaudhri OB, Patterson M, Thompson EL, Murphy KG, Badman MK, et al. Kisspeptin-54 Stimulates the Hypothalamic-Pituitary Gonadal Axis in Human Males. J Clin Endocrinol Metab (2005) 90:6609-15. doi: $10.1210 / j c .2005-1468$

97. Prague JK, Dhillo WS. Potential Clinical Use of Kisspeptin. Neuroendocrinology (2015) 102:238-45. doi: 10.1159/000439133

98. Abbara A, Eng PC, Phylactou M, Clarke SA, Richardson R, Sykes CM, et al. Kisspeptin Receptor Agonist Has Therapeutic Potential for Female Reproductive Disorders. J Clin Invest (2020) 130:6739-53. doi: 10.1172/ JCI139681

99. Beltramo M, Decourt C. Towards New Strategies to Manage Livestock Reproduction Using Kisspeptin Analogs. Theriogenology (2018) 112:2-10. doi: 10.1016/j.theriogenology.2017.08.026

100. Yeo SH, Herbison AE. Projections of Arcuate Nucleus and Rostral Periventricular Kisspeptin Neurons in the Adult Female Mouse Brain. Endocrinology (2011) 152:2387-99. doi: 10.1210/en.2011-0164

101. Merkley CM, Coolen LM, Goodman RL, Lehman MN. Evidence for Changes in Numbers of Synaptic Inputs Onto KNDy and GnRH Neurones During the Preovulatory LH Surge in the Ewe. J Neuroendocrinol (2015) 27:624-35. doi: $10.1111 /$ jne. 12293

102. de Croft S, Boehm U, Herbison AE. Neurokinin B Activates Arcuate Kisspeptin Neurons Through Multiple Tachykinin Receptors in the Male Mouse. Endocrinology (2013) 154:2750-60. doi: 10.1210/en.2013-1231

103. Pennefather JN, Lecci A, Candenas ML, Patak E, Pinto FM, Maggi CA. Tachykinins and Tachykinin Receptors: A Growing Family. Life Sci (2004) 74:1445-63. doi: 10.1016/j.lfs.2003.09.039

104. Rance NE. Young 3rd WS. Hypertrophy and Increased Gene Expression of Neurons Containing Neurokinin-B and Substance-P Messenger Ribonucleic Acids in the Hypothalami of Postmenopausal Women. Endocrinology (1991) 128:2239-47. doi: 10.1210/endo-128-5-2239

105. Guran T, Tolhurst G, Bereket A, Rocha N, Porter K, Turan S, et al. Hypogonadotropic Hypogonadism Due to a Novel Missense Mutation in the First Extracellular Loop of the Neurokinin B Receptor. J Clin Endocrinol Metab (2009) 94:3633-9. doi: 10.1210/jc.2009-0551

106. Topaloglu AK, Reimann F, Guclu M, Yalin AS, Kotan LD, Porter KM, et al. TAC3 and TACR3 Mutations in Familial Hypogonadotropic Hypogonadism Reveal a Key Role for Neurokinin B in the Central Control of Reproduction. Nat Genet (2009) 41:354-8. doi: 10.1038/ng.306

107. Akil H, Watson SJ, Young E, Lewis ME, Khachaturian H, Walker JM. Endogenous Opioids: Biology and Function. Annu Rev Neurosci (1984) 7:223-55. doi: 10.1146/annurev.ne.07.030184.001255

108. Goodman RL, Coolen LM, Anderson GM, Hardy SL, Valent M, Connors JM, et al. Evidence That Dynorphin Plays a Major Role in Mediating
Progesterone Negative Feedback on Gonadotropin-Releasing Hormone Neurons in Sheep. Endocrinology (2004) 145:2959-67. doi: 10.1210/ en.2003-1305

109. Foradori CD, Goodman RL, Adams VL, Valent M, Lehman MN. Progesterone Increases Dynorphin a Concentrations in Cerebrospinal Fluid and Preprodynorphin Messenger Ribonucleic Acid Levels in a Subset of Dynorphin Neurons in the Sheep. Endocrinology (2005) 146:1835-42. doi: 10.1210/en.2004-1326

110. Foradori CD, Amstalden M, Goodman RL, Lehman MN. Colocalisation of Dynorphin A and Neurokinin B Immunoreactivity in the Arcuate Nucleus and Median Eminence of the Sheep. J Neuroendocrinol (2006) 18:534-41. doi: 10.1111/j.1365-2826.2006.01445.x

111. Hrabovszky E, Ciofi P, Vida B, Horvath MC, Keller E, Caraty A, et al. The Kisspeptin System of the Human Hypothalamus: Sexual Dimorphism and Relationship With Gonadotropin-Releasing Hormone and Neurokinin B Neurons. Eur JNeurosci (2010) 31:1984-98. doi: 10.1111/j.1460-9568.2010.07239.x

112. Hrabovszky E, Sipos MT, Molnar CS, Ciofi P, Borsay BA, Gergely P, et al. Low Degree of Overlap Between Kisspeptin, Neurokinin B, and Dynorphin Immunoreactivities in the Infundibular Nucleus of Young Male Human Subjects Challenges the KNDy Neuron Concept. Endocrinology (2012) 153:4978-89. doi: 10.1210/en.2012-1545

113. Molnar CS, Vida B, Sipos MT, Ciofi P, Borsay BA, Racz K, et al. Morphological Evidence for Enhanced Kisspeptin and Neurokinin B Signaling in the Infundibular Nucleus of the Aging Man. Endocrinology (2012) 153:5428-39. doi: 10.1210/en.2012-1739

114. Skrapits K, Borsay BA, Herczeg L, Ciofi P, Bloom SR, Ghatei MA, et al. Colocalization of Cocaine- and Amphetamine-Regulated Transcript With Kisspeptin and Neurokinin B in the Human Infundibular Region. PloS One (2014) 9:e103977. doi: 10.1371/journal.pone.0103977

115. Ruka KA, Burger LL, Moenter SM. Regulation of Arcuate Neurons Coexpressing Kisspeptin, Neurokinin B, and Dynorphin by Modulators of Neurokinin 3 and Kappa-Opioid Receptors in Adult Male Mice. Endocrinology (2013) 154:2761-71. doi: 10.1210/en.2013-1268

116. Amstalden M, Coolen LM, Hemmerle AM, Billings HJ, Connors JM, Goodman RL, et al. Neurokinin 3 Receptor Immunoreactivity in the Septal Region, Preoptic Area and Hypothalamus of the Female Sheep: Colocalisation in Neurokinin B Cells of the Arcuate Nucleus But Not in Gonadotrophin-Releasing Hormone Neurones. J Neuroendocrinol (2010) 22:1-12. doi: 10.1111/j.1365-2826.2009.01930.x

117. Tsuchida H, Mostari P, Yamada K, Miyazaki S, Enomoto Y, Inoue N, et al. Paraventricular Dynorphin A Neurons Mediate LH Pulse Suppression Induced by Hindbrain Glucoprivation in Female Rats. Endocrinology (2020) 161:bqaa161. doi: 10.1210/endocr/bqaa161

118. Weems PW, Witty CF, Amstalden M, Coolen LM, Goodman RL, Lehman MN. Kappa Opioid Receptor Is Co-Localized in GnRH and KNDy Cells in the Female Ovine and Rat Brain. Endocrinology (2016) 157:2367-79. doi: 10.1210/en.2015-1763

119. Sasaki T, Ito D, Sonoda T, Morita Y, Wakabayashi Y, Yamamura T, et al. Peripheral Administration of Kappa-Opioid Receptor Antagonist Stimulates Gonadotropin-Releasing Hormone Pulse Generator Activity in Ovariectomized, Estrogen-Treated Female Goats. Domest Anim Endocrinol (2019) 68:83-91. doi: 10.1016/j.domaniend.2018.12.011

120. Sasaki T, Sonoda T, Tatebayashi R, Kitagawa Y, Oishi S, Yamamoto K, et al. Peripheral Administration of SB223412, a Selective Neurokinin-3 Receptor Antagonist, Suppresses Pulsatile Luteinizing Hormone Secretion by Acting on the Gonadotropin-Releasing Hormone Pulse Generator in EstrogenTreated Ovariectomized Female Goats. J Reprod Dev (2020) 66:351-7. doi: 10.1262/jrd.2019-145

121. Goodman RL, Hileman SM, Nestor CC, Porter KL, Connors JM, Hardy SL, et al. Kisspeptin, Neurokinin B, and Dynorphin Act in the Arcuate Nucleus to Control Activity of the GnRH Pulse Generator in Ewes. Endocrinology (2013) 154:4259-69. doi: 10.1210/en.2013-1331

122. Lehman MN, He W, Coolen LM, Levine JE, Goodman RL. Does the KNDy Model for the Control of Gonadotropin-Releasing Hormone Pulses Apply to Monkeys and Humans? Semin Reprod Med (2019) 37:71-83. doi: 10.1055/s0039-3400254

123. Nagae M, Uenoyama Y, Okamoto S, Tsuchida H, Ikegami K, Goto T, et al. Direct Evidence That KNDy Neurons Maintain Gonadotropin Pulses and 
Folliculogenesis as the GnRH Pulse Generator. Proc Natl Acad Sci USA (2021) 118:e2009156118. doi: 10.1073/pnas.2009156118

124. Popa SM, Moriyama RM, Caligioni CS, Yang JJ, Cho CM, Concepcion TL, et al. Redundancy in Kiss1 Expression Safeguards Reproduction in the Mouse. Endocrinology (2013) 154:2784-94. doi: 10.1210/en.2013-1222

125. Krajewski SJ, Anderson MJ, Iles-Shih L, Chen KJ, Urbanski HF, Rance NE. Morphologic Evidence That Neurokinin B Modulates Gonadotropin-Releasing Hormone Secretion via Neurokinin 3 Receptors in the Rat Median Eminence. J Comp Neurol (2005) 489:372-86. doi: 10.1002/cne.20626

126. Weems PW, Coolen LM, Hileman SM, Hardy S, McCosh RB, Goodman RL, et al. Evidence That Dynorphin Acts Upon KNDy and GnRH Neurons During GnRH Pulse Termination in the Ewe. Endocrinology (2018) 159:3187-99. doi: 10.1210/en.2018-00435

127. Noritake KI, Suzuki J, Matsuoka T, Makino T, Ohnishi H, Shimomura K, et al. Testicular Toxicity Induced by a Triple Neurokinin Receptor Antagonist in Male Dogs. Reprod Toxicol (2011) 31:440-6. doi: 10.1016/j.reprotox.2010.12.007

128. Noritake KI, Matsuoka T, Ohsawa T, Shimomura K, Sanbuissho A, Uenoyama Y, et al. Involvement of Neurokinin Receptors in the Control of Pulsatile Luteinizing Hormone Secretion in Rats. J Reprod Dev (2011) 57:409-15. doi: 10.1262/jrd.11-002S

129. Hrabovszky E, Molnar CS, Sipos MT, Vida B, Ciofi P, Borsay BA, et al. Sexual Dimorphism of Kisspeptin and Neurokinin B Immunoreactive Neurons in the Infundibular Nucleus of Aged Men and Women. Front Endocrinol (2011) 2:80. doi: $10.3389 /$ fendo.2011.00080

130. Moore AM, Coolen LM, Porter DT, Goodman RL, Lehman MN. KNDy Cells Revisited. Endocrinology (2018) 159:3219-34. doi: 10.1210/en.2018-00389

Conflict of Interest: The authors declare that the research was conducted in the absence of any commercial or financial relationships that could be construed as a potential conflict of interest.

Publisher's Note: All claims expressed in this article are solely those of the authors and do not necessarily represent those of their affiliated organizations, or those of the publisher, the editors and the reviewers. Any product that may be evaluated in this article, or claim that may be made by its manufacturer, is not guaranteed or endorsed by the publisher.

Copyright (c) 2021 Uenoyama, Nagae, Tsuchida, Inoue and Tsukamura. This is an open-access article distributed under the terms of the Creative Commons Attribution License (CC BY). The use, distribution or reproduction in other forums is permitted, provided the original author(s) and the copyright owner(s) are credited and that the original publication in this journal is cited, in accordance with accepted academic practice. No use, distribution or reproduction is permitted which does not comply with these terms. 